\title{
Stability and Electric Conductivity of Barium Cerate Perovskites Co-Doped with Praseodymium
}

\author{
J. Melnik, J. Luo ${ }^{*}$ K.T. Chuang and A.R. Sanger
}

Department of Chemical and Materials Engineering, University of Alberta, Edmonton, Alberta, Canada T6G $2 G 6$

\begin{abstract}
Co-doping of yttrium doped mixed barium cerate/zirconate perovskite (BCZY) with small amounts of Pr (BCZYP) substantially increases electrical conductivity while retaining structural and chemical stability. BCZYP is predominantly a proton conductor at temperatures up to $600-650^{\circ} \mathrm{C}$, whereas it is a mixed proton/oxide ion/electron conductor at higher temperatures. The co-doped BCZYP perovskite can be useful for applications requiring proton conduction at intermediate temperatures.
\end{abstract}

\section{INTRODUCTION}

High-temperature proton-conducting perovskites are a promising class of materials for use as solid electrolytes in applications including hydrogen and hydrocarbon sensors, hydrogen separation, solid oxide fuel cells (SOFC), electrochemical hydrogenation and dehydrogenation of organic compounds [1].

Doped perovskites $\mathrm{AB}_{(1-\mathrm{c})} \mathrm{C}_{\mathrm{c}} \mathrm{O}_{3-\boldsymbol{\delta}}$ (where $\mathrm{A}$ is $\mathrm{Ca}, \mathrm{Sr}, \mathrm{Ba}$; $\mathrm{B}$ is $\mathrm{Ce}, \mathrm{Zr}, \mathrm{Ti}$; and $\mathrm{C}$ is $\mathrm{Sc}, \mathrm{Y}, \mathrm{Ln})$ are attractive options for use as electrolytes due to their relatively high protonic conduction and thermodynamic stability [2-4]. Among proven strong protonic electrolytes, the order of conductivity is: $\mathrm{BaCeO}_{3}>\mathrm{SrCeO}_{3}>\mathrm{BaZrO}_{3}>\mathrm{CaZrO}_{3}$. Each of these materials exhibits high temperature protonic conduction when oxide ion vacancies are introduced by partial substitution of $\mathrm{C}^{+3}$ cations for $\mathrm{B}^{+4}$ cations. Such acceptor doping with trivalent ions creates negatively charged defects $C_{B}$ ' and oxygen vacancies $\mathrm{V}_{\mathrm{O}}$ " (Kröger-Vink notation):

$2 \mathrm{~B}_{\mathrm{B}}{ }^{\mathrm{x}}+\mathrm{O}_{\mathrm{O}}{ }^{\mathrm{x}}+\mathrm{C}_{2} \mathrm{O}_{3}=2 \mathrm{C}_{\mathrm{B}}{ }^{\prime}+\mathrm{V}_{\mathrm{O}}{ }^{\cdot}+2 \mathrm{BO}_{2}$

Subsequent exposure to humid atmosphere (Eq. 2) and/or hydrogen (Eq. 3) at high temperature leads to the incorporation of protons associated with the oxygen ions $\mathrm{OH}_{\mathrm{O}}$, and consequently to protonic conduction:

$$
\begin{aligned}
& \mathrm{H}_{2} \mathrm{O}_{(\mathrm{g})}+\mathrm{V}_{\mathrm{O}}{ }^{\circ}+\mathrm{O}_{\mathrm{O}}{ }^{\mathrm{x}}=2 \mathrm{OH}_{\mathrm{O}}{ }^{\circ} \\
& 0.5 \mathrm{H}_{2(\mathrm{~g})}+\mathrm{O}_{\mathrm{O}}{ }^{\mathrm{x}}=\mathrm{OH}_{\mathrm{O}}{ }^{\prime}+\mathrm{e}^{\prime}
\end{aligned}
$$

The necessary (but not sufficient) conditions of high protonic conduction in perovskites are: (I) basic metal cations at A sites having strong chemical tendency to hydrate; (II) partial substitution of cations introducing oxide ion vacancies for B-site cations; (III) high level of the Goldschmidt tolerance factor, requiring the sizes of dopant and host atoms to be nearly the same; and (IV) optimal amount of a dopant to provide sufficient density of protonic defects.

Unfortunately, it has been found that several doped cerates having relatively high conductivity also have low

*Address correspondence to this author at the Department of Chemical and Materials Engineering, University of Alberta, Edmonton, Alberta, Canada T6G 2G6; E-mail: jingli.luo@ualberta.ca chemical stability at elevated temperatures, therefore compromising commercial application of these types of perovskites. For example, barium cerate is unstable in the presence of $\mathrm{CO}_{2}$ (Eq. 4), humidity (Eq. 5), and under humid reductive conditions (Eq. 6):

$$
\begin{aligned}
& \mathrm{BaCeO}_{3}+\mathrm{CO}_{2}=\mathrm{BaCO}_{3}+\mathrm{CeO}_{2} \\
& \mathrm{BaCeO}_{3}+\mathrm{H}_{2} \mathrm{O}=\mathrm{Ba}(\mathrm{OH})_{2}+\mathrm{CeO}_{2} \\
& 2 \mathrm{BaCeO}_{3}+\mathrm{H}_{2}+\mathrm{H}_{2} \mathrm{O}=2 \mathrm{Ba}(\mathrm{OH})_{2}+\mathrm{Ce}_{2} \mathrm{O}_{3}
\end{aligned}
$$

In contrast, barium zirconate $\left(\mathrm{BaZrO}_{3}\right)$ is stable under the conditions mentioned above. Partial substitution of $\mathrm{Zr}^{+4}$ cations for $\mathrm{Ce}^{+4}$ cations of $\mathrm{BaCeO}_{3}$ provided a partly substituted perovskite $\mathrm{Ba}(\mathrm{Ce}, \mathrm{Zr}) \mathrm{O}_{3}$ having a better stability when compared with that of $\mathrm{BaCeO}_{3}[5,6]$. However, zirconiabased protonic conductors have much lower conductivity than the corresponding cerates. Thus, while substitution of $\mathrm{Ce}$ by $\mathrm{Zr}$ improves chemical stability (especially in $\mathrm{CO}_{2}$ atmosphere), it decreases conductivity. Haile et al. [5] and Iwahara et al. [6] reported $\mathrm{Zr}$-substituted $\mathrm{BaCeO}_{3}$ compositions having an optimal compromise between conductivity and stability. However, the best proton conductivities achieved were still not sufficient for commercial applications where power densities over $0.1 \mathrm{~W} / \mathrm{cm}^{2}$ are required [1]. Consequently, there is a requirement for more efficient electrolytes having improved conductivity without stability deterioration.

It has recently been shown that perovskites doped with praseodymium have unusually high conductivity and, notably, this can be achieved at relatively low and intermediate temperatures [7-13]. In particular, $\mathrm{BaPr}_{(1-\mathrm{g})} \mathrm{Gd}_{\mathrm{g}} \mathrm{O}_{3-\delta}$ has conductivity ranging from $5 \times 10^{-3} \mathrm{~S} \mathrm{~cm}^{-1}$ at $200^{\circ} \mathrm{C}$ to $0.5 \mathrm{~S} \mathrm{~cm}^{-1}$ at $700^{\circ} \mathrm{C}$, values that are about one order of magnitude higher than conductivity of the benchmark barium cerates. Moreover, this material exhibits predominant proton conductivity at low temperatures: $200-500^{\circ} \mathrm{C}$. At intermediate temperatures $\left(500-700^{\circ} \mathrm{C}\right)$ it is a mixed proton, oxygen ion and electronic (hole-type) conductor. Pr and $\mathrm{Ce}$ ions have very similar crystal and chemical properties and consequently are compatible in the perovskite crystal lattice. Pr readily forms materials containing more than one oxidation state, as in $\operatorname{Pr}_{6} \mathrm{O}_{11}$, and so, more than $\mathrm{Ce}$ and, a fortiori, $\mathrm{Zr}$, enhances capability for electrochemical activity through transitions 
between oxidation states of adjacent Pr centers within the lattice, including electrical properties and mixed character of conductivity of Pr-containing materials. However, the chemical stability of $\mathrm{BaPrO}_{3}, \mathrm{BaPr}_{(1-\mathrm{g})} \mathrm{Gd}_{\mathrm{g}} \mathrm{O}_{3-\delta}$ and related materials is rather poor (e.g. Eq. 7):

$2 \mathrm{BaPrO}_{3}+2 \mathrm{CO}_{2}+\mathrm{H}_{2}=2 \mathrm{BaCO}_{3}+\mathrm{Pr}_{2} \mathrm{O}_{3}+\mathrm{H}_{2} \mathrm{O}$

Herein we describe the impact of co-doping $\mathrm{BCY}$ and BCZY with small amounts of Pr to take advantage of the potential for synergetic enhancement of conductivity through incorporation of Pr, and to determine if such doping compromised the stability of the $\mathrm{Zr}$-substituted perovskite BCZY. The microstructure, stability and electrochemical properties of the new materials have been investigated and compared with the undoped materials.

\section{MATERIALS AND METHODOLOGY}

Polycrystalline samples of $\mathrm{BaCe}_{(1-\mathrm{y})} \mathrm{Y}_{\mathrm{y}} \mathrm{O}_{3-\delta}$ (BCY), $\mathrm{BaCe}_{(1-\mathrm{z}-\mathrm{y})} \mathrm{Zr}_{\mathrm{z}} \mathrm{Y}_{\mathrm{y}} \mathrm{O}_{3-\delta}(\mathrm{BCZY}), \mathrm{BaCe}_{(1-\mathrm{y}-\mathrm{p})} \mathrm{Y}_{\mathrm{y}} \mathrm{Pr}_{\mathrm{p}} \mathrm{O}_{3-\delta}$ (BCYP), and $\mathrm{BaCe}_{(1-\mathrm{z}-\mathrm{y}-\mathrm{p})} \mathrm{Zr}_{\mathrm{z}} \mathrm{Y}_{\mathrm{y}} \mathrm{Pr}_{\mathrm{p}} \mathrm{O}_{3-\delta}(\mathrm{BCZYP})$, where $\mathrm{z}=0.4-0.5 ; \mathrm{y}$ $=0.15-0.20 ;$ and $\mathrm{p}=0.03-0.05$, were synthesized using conventional solid-state synthesis from $\mathrm{BaCO}_{3}$ (99.98\%, Aldrich) and nanopowders of $\mathrm{CeO}_{2}, \mathrm{ZrO}_{2}, \mathrm{Y}_{2} \mathrm{O}_{3}$ (Inframat Advanced Materials) and $\operatorname{Pr}_{6} \mathrm{O}_{11}(99 \%$, Aldrich). Ball-milled raw mixes were calcined at $1200^{\circ} \mathrm{C}$ for $10 \mathrm{~h}$ in air. Then they were again ball-milled, pressed into disk samples $(20 \mathrm{~mm}$ in diameter) and sintered at $1600-1650^{\circ} \mathrm{C}$ for $12 \mathrm{~h}$ in air. Both sides of each sintered disk were polished to remove from the surface a layer of any adventitious materials that may have been formed through thermal decomposition or phase segregation.

Phase compositions and microstructures of new materials were determined using X-ray diffraction analysis (XRD, Rigaku X-ray diffractmeter), thermo-gravimetric analysis (TGA, NETZSCH STA 409PC system) and scanning electron microscopy (SEM/EDX analysis using a PGT Imix system).

Disks having screen printed platinum electrodes with the area of $0.3 \mathrm{~cm}^{2}$ were used in all electrochemical measurements. Conductivity was measured using electrochemical ac impedance spectroscopy with a Solartron 1287 frequency response analyzer. The same Solartron system was used for various electrical measurements in hydrogen concentration cells and for determination of performance of the electrolytes in $\mathrm{H}_{2}-\mathrm{O}_{2}$ fuel cells.

\section{RESULTS AND DISCUSSION}

$\mathrm{BaCO}_{3}$ and nanopowders of $\mathrm{CeO}_{2}, \mathrm{ZrO}_{2}, \mathrm{Y}_{2} \mathrm{O}_{3}$ and $\mathrm{Pr}_{6} \mathrm{O}_{11}$ were taken in designed proportions, mixed in isopropanol using ball milling to form uniform mixtures, and then calcined to form polycrystalline samples of the known perovskites BCY and BCZY, and the corresponding new $\mathrm{Pr}$ co-doped perovskites BCYP and BCZYP. The materials were in each case single perovskite phases with an appropriate crystallinity (XRD: Fig. (1)). Then the calcined samples were ball-milled again, pressed into disks and sintered at $1600-1650^{\circ} \mathrm{C}$ for $12 \mathrm{~h}$ in air. Sintered samples had apparent densities in the $90-96 \%$ range when compare to theoretical values (as calculated by weight and volume). They were very dense and contained very few voids (SEM: Fig. (1)). Thus, the obtained materials were highly crystalline perovskites that had good bulk structure suitable for providing electrical conduction by intimate contact between adjacent domains.
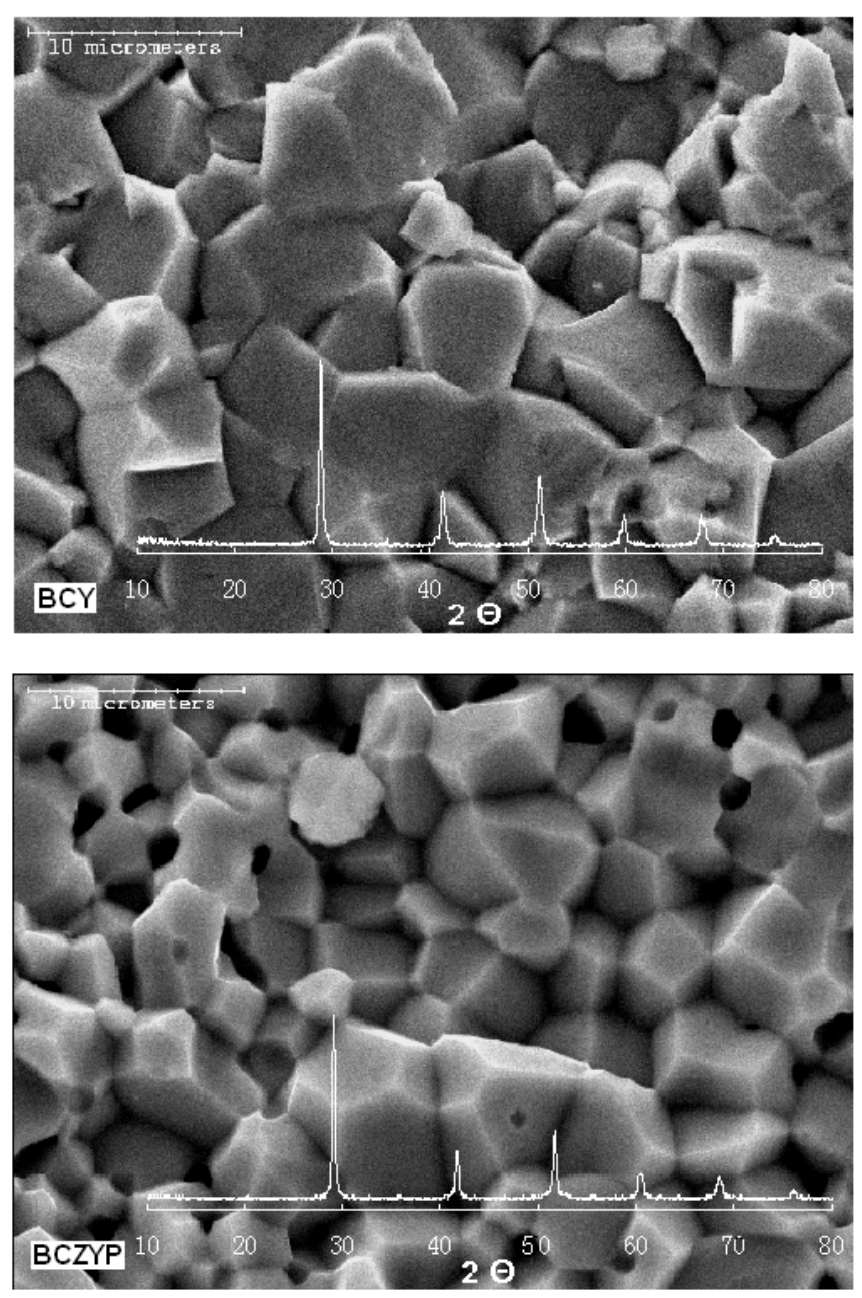

Fig. (1). SEM images (fracture surface) and XRD patterns (plotted on the images) of BCY and BCZYP perovskites.

Before testing electrochemical properties of the new materials, it was necessary to evaluate the chemical stability of the perovskites in atmospheres containing $\mathrm{CO}_{2}$, which is a typical component or co-product of many fuel cell feed gases (syngas, hydrocarbons, etc.). Thermo-gravimetric analyses of powdered samples treated in pure $\mathrm{CO}_{2}$ showed that barium oxide was eliminated for those barium cerate perovskites doped with either of $\mathrm{Y}$ or both $\mathrm{Y}$ and $\mathrm{Pr}$ and which contained no $\mathrm{Zr}$, to the extent of about $90 \%$ for BCYP and $97 \%$ for $\mathrm{BCY}$ at temperatures over $500^{\circ} \mathrm{C}$ (Fig. 2). The weight gain corresponded to reaction of the $\mathrm{Ba}$ content with $\mathrm{CO}_{2}$ to form $\mathrm{BaCO}_{3}$. When the sample was heated further, the so-formed carbonate component of the mixtures decomposed with release of $\mathrm{CO}_{2}$ at temperatures over $1050^{\circ} \mathrm{C}$ $(\mathrm{BCY})$ and $1150^{\circ} \mathrm{C}(\mathrm{BCYP})$. Thus the perovskites containing no $\mathrm{Zr}$ were chemically unstable in $\mathrm{CO}_{2}$-containing atmospheres, in agreement with literature data [5,6]. In contrast, the perovskites containing a combination of $\mathrm{Zr}$ with $\mathrm{Pr}$ and/or Y did not react with $\mathrm{CO}_{2}$. Thus substitution with $\mathrm{Zr}$ conferred chemical stability, whether or not $\mathrm{Y}$ and Pr were present in the materials.

Bulk conductivities of the electrolytes were measured in air saturated with water vapor $\left(P_{\text {sat }} \approx 4 \mathrm{kPa}\right)$ using disks with 
Pt electrodes. The conductivity of BCZY was less than that

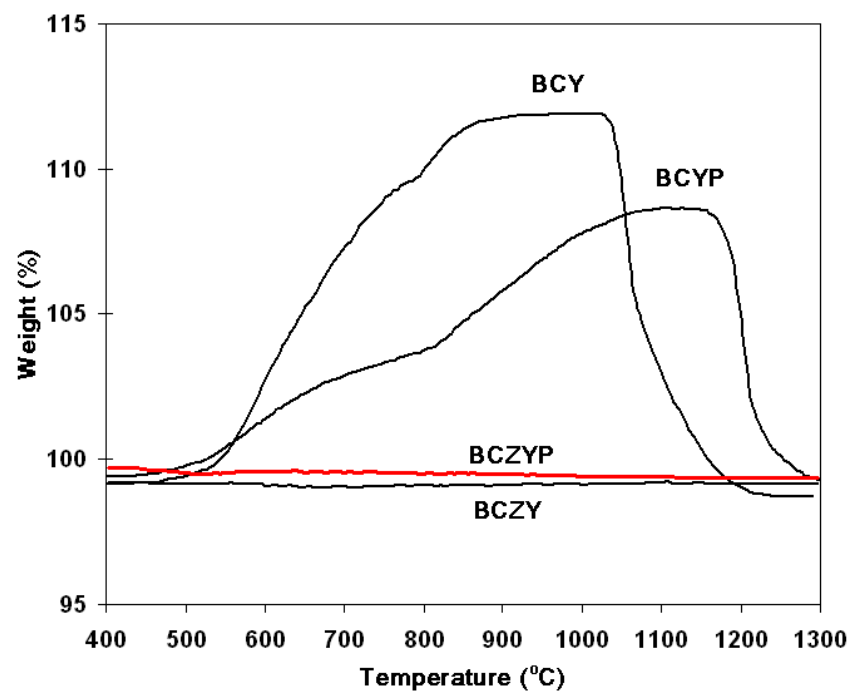

Fig. (2). Thermo-gravimetric profiles for different barium cerate perovskites.

of BCY, in agreement with literature data [4-6]. The new electrolytes, Pr co-doped BCYP and BCZYP, had higher bulk conductivities than their corresponding parent $\mathrm{BCY}$ and BCZY perovskites within the temperature range $500-800^{\circ} \mathrm{C}$, by factors of 1.5-2 and 2.5-4 respectively (Fig. 3). The values of the bulk conductivity of BCZYP were slightly higher than those of BCY, with the advantage that the $\mathrm{Zr}$ content conferred good stability. Thus the effectiveness and value of co-doping barium cerate-based perovskites with both $\mathrm{Zr}$ and Pr is apparent.

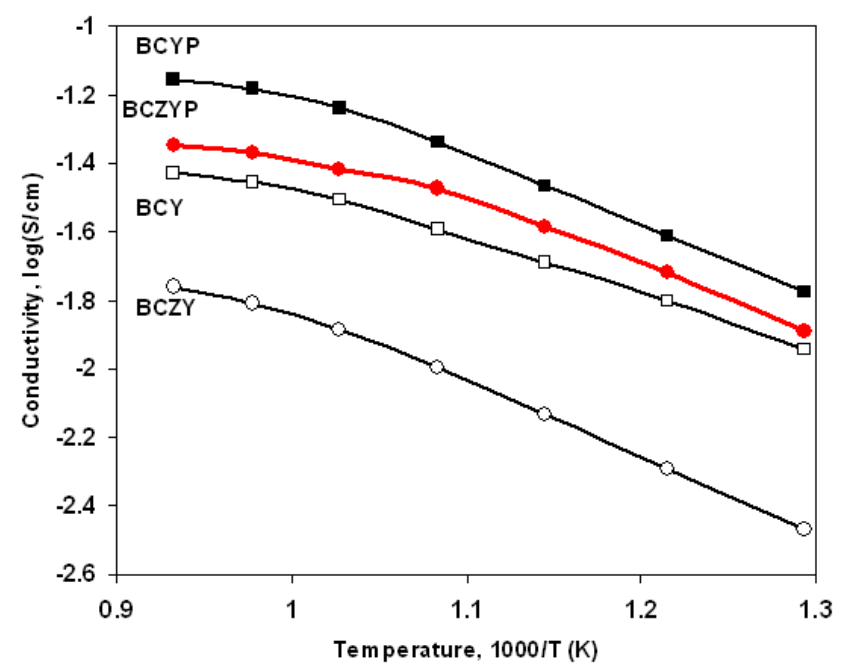

Fig. (3). Bulk conductivities of different barium cerate perovskites in humidified air.

Having shown that the Pr doped perovskites were stable and had good conductivity, [Pt/electrolyte/Pt] membrane assemblies were prepared for hydrogen concentration cell and $\mathrm{H}_{2}-\mathrm{O}_{2}$ fuel cell tests.

Electromotive force (EMF) values determined using the hydrogen concentration cell for both BCY and BCZYP electrolytes at intermediate temperatures $\left(500-650^{\circ} \mathrm{C}\right)$ were close to theoretical values (calculated proton transport numbers are higher than 0.9), which showed that the major conduction mechanism was protonic in this temperature range (Fig. 4). In contrast, a significant level of mixed conductivity was evident at temperatures higher than $650^{\circ} \mathrm{C}$, and significantly so for BCZYP. However, the data shown in Fig. (4) were insufficiently discriminating to determine the proportional changes in slopes of Arrhenius plots for different types of conductivities (Fig. 3), indicating that there was a complex mixed proton/oxygen ion/electron conduction mechanism in these electrolytes tested in wet air.

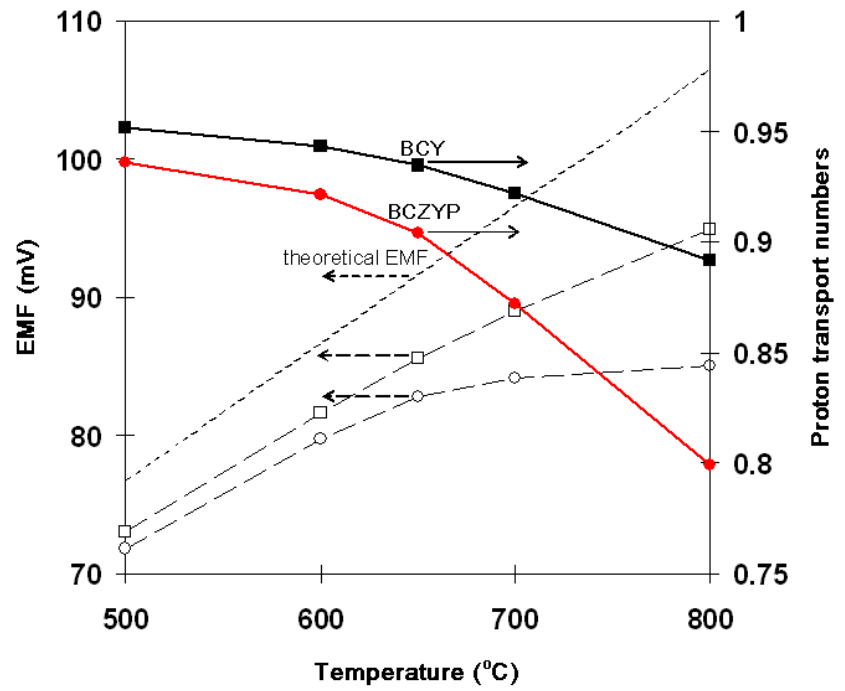

Fig. (4). EMF of hydrogen concentration cells and hydrogen transport numbers for BCY and BCZYP.

The short-circuit current densities of a BCZYP electrolyte with a thickness of $1 \mathrm{~mm}$ in a hydrogen concentration cell $\left(100 \% \mathrm{H}_{2} / 10 \% \mathrm{H}_{2}\right)$ reached values about $5 \mathrm{mAcm}^{-2}$ at $650^{\circ} \mathrm{C}$. Accordingly, the hydrogen permeation rate estimated using Faraday's law was up to $0.07 \mathrm{~cm}^{3}(\mathrm{STP}) \mathrm{cm}^{-2} \mathrm{~min}^{-1}$, a value comparable with those of other strongly proton conducting perovskites [14-17].

The electrical performance of the perovskites was tested during operation of a hydrogen fuel cell. Membranes of 1 $\mathrm{mm}$ thickness were used, and Pt electrodes were applied to each side. The assemblies so prepared were then tested in a laboratory fuel cell comprising opposed coaxial chambers in which humidified $\mathrm{H}_{2}$ and $\mathrm{O}_{2}$ were flowing at opposite faces of the assembly. In each case the electrolyte performance was stable during operation for several hours. None of the BCZYP electrolytes tested was subject to surface deterioration. When BCY and BCZYP were compared, it was readily apparent that both electrolytes were capable of sustaining closely similar OCVs and current densities at $650^{\circ} \mathrm{C}$ (Fig. 5). Thus, the presence of small amounts of Pr supports proton conduction in barium cerate perovskites at intermediate temperatures and evidently increases total conductivity when compared to that of BCZY (Fig. 3).

It has long been recognized that thin membranes are required for high power density fuel cells. A membrane comprising a thin layer (30 microns) of BCZYP electrolyte supported with a LSM+BCZYP (LSM is $\mathrm{La}_{0.8} \mathrm{Sr}_{0.2} \mathrm{MnO}_{3-\delta}$ from Fuel Cell Materials) porous cathode tested using the same 
fuel cell configuration had high electrochemical performance (about $0.3 \mathrm{~W}^{\circ} \mathrm{cm}^{-2}$ at $650^{\circ} \mathrm{C}$; Fig. (6)).

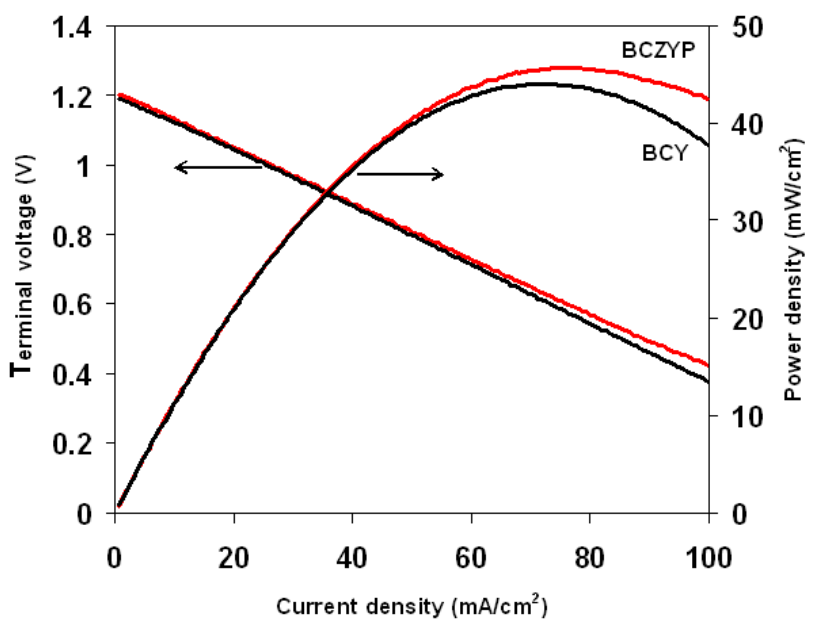

Fig. (5). Electrical performance at $650^{\circ} \mathrm{C}$ of $\mathrm{BCY}$ and $\mathrm{BCZYP}$ membranes ( $1 \mathrm{~mm}$ thick) in the $\mathrm{H}_{2}-\mathrm{O}_{2}$ fuel cell.

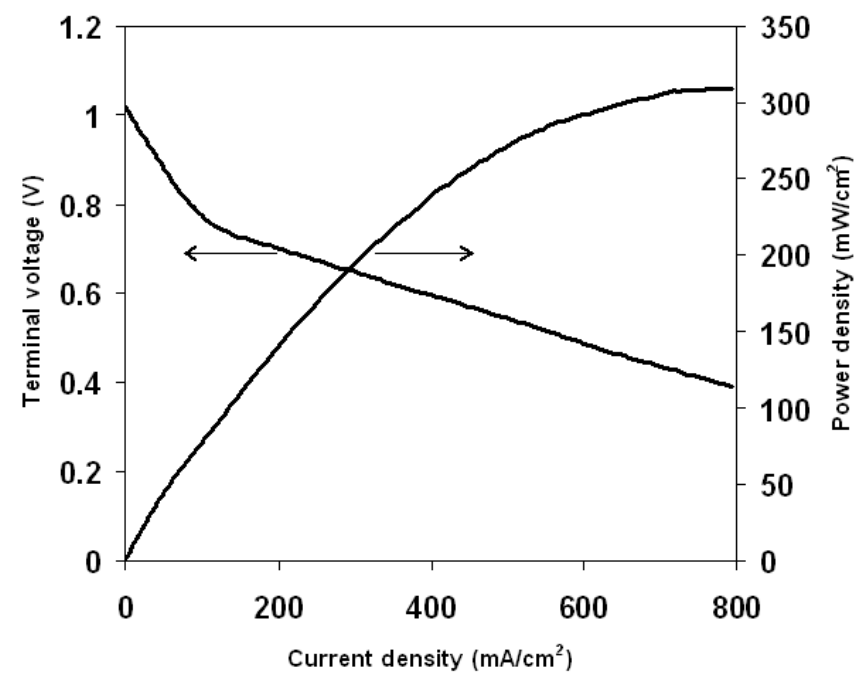

Fig. (6). Electrical performance at $650^{\circ} \mathrm{C}$ of cathode supported thin layer BCZYP electrolyte (30 microns) in the $\mathrm{H}_{2}-\mathrm{O}_{2}$ fuel cell.

While the latter result requires further detailed investigations on electrochemical and physical interaction between BCZYP and LSM as well as conduction mechanism in BCZYP electrolyte, it is clear that the BCZYP electrolyte has strong potential for use in hydrogen SOFCs, electrochemical separation membranes, and related applications at intermediate temperatures.

\section{CONCLUSIONS}

Co-doping of yttria-doped mixed barium cerate/zirconate perovskites with small amounts of Pr affords proton conductive ceramic electrolytes possessing both high electric conductivity (close to $10^{-1} \mathrm{~S}^{\circ} \mathrm{cm}^{-1}$ ) and acceptable chemical stability.

At temperatures up to $600-650^{\circ} \mathrm{C}$ BCZYP is predominantly a proton conductor, whereas at higher temperatures it is a mixed proton/oxide ion/electron conductor.

A $\mathrm{H}_{2}-\mathrm{O}_{2}$ fuel cell using a cathode-supported $30 \mu \mathrm{m}$ membrane of BCZYP as electrolyte had good performance, with power density over $300 \mathrm{~mW}^{\circ} \mathrm{cm}^{-2}$ at $650^{\circ} \mathrm{C}$.

Although the obtained electrolyte requires deeper investigations, it can be considered as a potential material for use in hydrogen SOFCs, electrochemical separation membranes, and related applications at intermediate temperatures.

\section{ACKNOWLEDGEMENT}

This work was supported by Natural Science and Engineering Research Council of Canada.

\section{REFERENCES}

[1] Schober, T. Solid State Ionics, 2003, 277, 162.

[2] Iwahara, H. Solid State Ionics, 1995, 77, 289.

[3] Kreuer, K.D. Аnnu. Rev. Mater. Res., 2003, 33, 333.

[4] Iwahara, H.; Asakura, Y.; Katahira, K.; Tanaka, M. Solid State Ionics, 2004, 168, 299.

[5] Ryu, K.H.; Haile, S.M. Solid State Ionics, 1999, 125, 355.

[6] Katahira, K.; Kohchi, Y.; Shimura, T.; Iwahara, H. Solid State Ionics, 2000, 138, 91.

[7] Fukui, T.; Ohara, S.; Kawatsu, S. Solid State Ionics, 1999, 116, 331.

[8] Li, L.; Wu, J.R.; Jian, R.; Haile, S.M. In High Temperature Corrosion and materials Chemistry III, Proceedings - Electrochemical Society, USA, 2001, 12, 214-223.

[9] Gorelov, V.P.; Kuzin, B.L.; Balakireva, V.B.; Sharova, N.V.; Vdovin, G.K.; Beresnev, S.M.; Kleshchev, Y.N.; Brusentsov, V.P. Russ. J. Electrochem., 2001, 37(5), 505.

[10] Liu, Z.; Cong, L.; Huang, X.; Lu, Z.; Su, W. J. Alloy Comp., 2001, 314, 281.

[11] Hirabayashi, D.; Tomita, A.; Brito, M.E.; Hibino, T.; Harada, U.; Nagao, M.; Sano, M. Solid State Ionics, 2004, 168, 23.

[12] Ren, Y.; Li, B.; Wang, J.; Xu, X. J. Solid State Chem., 2004, 177, 3977.

[13] Pelletier, L.; McFarlan, A.; Maffei, N. J. Power Sources, 2005, $145,262$.

[14] Guan, J.; Dorris, S.E.; Balachandran, U.; Liu, M. Solid State Ionics, 1998, 110, 303.

[15] Norby, T.; Larring, Y. Solid State Ionics, 2000, 139, 136.

[16] Hamakawa, S.; Li, L.; Li, A.; Iglesia, E. Solid State Ionics, 2002, $48,71$.

[17] Phair, J.W.; Badwal, S.P.S. Ionics, 2006, 12, 103. 